\title{
Cross-Comparison of Leaching Strains Isolated from Two Different Regions: Chambishi and Dexing Copper Mines
}

\author{
Baba Ngom, ${ }^{1,2}$ Yili Liang, ${ }^{1,2}$ and Xueduan Liu ${ }^{1,2}$ \\ ${ }^{1}$ School of Minerals Processing and Bioengineering, Central South University, Changsha, Hunan 410083, China \\ ${ }^{2}$ Key Laboratory of Biohydrometallurgy, Ministry of Education, Changsha 410083, China \\ Correspondence should be addressed to Xueduan Liu; xueduanliu@yahoo.com
}

Received 28 April 2014; Revised 23 July 2014; Accepted 12 August 2014; Published 16 November 2014

Academic Editor: Paula Loureiro Paulo

Copyright (c) 2014 Baba Ngom et al. This is an open access article distributed under the Creative Commons Attribution License, which permits unrestricted use, distribution, and reproduction in any medium, provided the original work is properly cited.

\begin{abstract}
A cross-comparison of six strains isolated from two different regions, Chambishi copper mine (Zambia, Africa) and Dexing copper mine (China, Asia), was conducted to study the leaching efficiency of low grade copper ores. The strains belong to the three major species often encountered in bioleaching of copper sulfide ores under mesophilic conditions: Acidithiobacillus ferrooxidans, Acidithiobacillus thiooxidans, and Leptospirillum ferriphilum. Prior to their study in bioleaching, the different strains were characterized and compared at physiological level. The results revealed that, except for copper tolerance, strains within species presented almost similar physiological traits with slight advantages of Chambishi strains. However, in terms of leaching efficiency, native strains always achieved higher cell density and greater iron and copper extraction rates than the foreign microorganisms. In addition, microbial community analysis revealed that the different mixed cultures shared almost the same profile, and At. ferrooxidans strains always outcompeted the other strains.
\end{abstract}

\section{Introduction}

Bioleaching is the extraction of specific metals such as gold and copper from their ores through the exploitation of the oxidative activity of some microbial species, mainly sulfur and iron oxidizers [1]. Most of these ores are mineral sulfides categorized into "acid-soluble" and "acid-insoluble" metal sulfides. These two types of minerals are dissolved through two different pathways: thiosulfate pathway for acid-insoluble minerals and polysulfide pathway for acid-soluble metal sulfide ores $[2,3]$. For both cases, leaching microbes provide the main leaching agents which consist of ferric iron and proton $\mathrm{H}^{+}[4,5]$. Over the last decades, a lot of work has been conducted on leaching microbes, and the descriptions of most of known microorganisms involved in biohydrometallurgy are well documented [4]. Several recent reviews have given a broad view of the microbial diversity within mining biotopes [6-8]. Even though huge efforts have been made on understanding such microorganisms, finding the suitable microorganisms or microbial combination, which may perform a high leaching efficiency and work under extreme environmental conditions, remains a huge challenge [9]. The efficiency is rather a result of the interaction of different microorganisms with different physiology than the action of a single microorganism [9]. However, physiological traits are not cumulative, and a microbial community composed of microorganisms with the most interesting physiological traits would not necessarily perform the best leaching efficiency in a given mineral ore [10]. Foreign strains such as commercially available microbial reference strains often prove ineffective for the leaching of new metal sulfides ores, due to their difficulty to adapt to and survive on the sulfides and other minerals present in an ore [11]. Therefore, more robust microbes and microbial combinations are being sought to enhance the bioleaching of these minerals. The use of native microbes, acclimatized to a given sulfide ore through many generations, may be one option for increasing viability and improving metal extraction efficiency. So this study aimed at investigating the leaching efficiency of native and foreign leaching microorganisms for the bioleaching of low grade copper ores.

For the purpose of this study, we compared some bacteria isolated from the Chambishi copper mine in Chambishi 
TABLE 1: Chemical and copper mineral composition (\% wt/wt) of Chambishi and Dexing minerals samples.

\begin{tabular}{lccccc}
\hline Components & Chambishi & Dexing & Copper minerals & Chambishi & Dexing \\
\hline $\mathrm{Cu}$ & 0.221 & 0.591 & Free copper oxide & $\mathbf{0 . 1 6}$ & 0.03 \\
$\mathrm{Fe}$ & 1.991 & 6.612 & Combined copper oxide & 0.032 & 0.011 \\
$\mathrm{~S}$ & 0.224 & 2.563 & Secondary copper sulfide & 0.021 & 0.08 \\
$\mathrm{As}, \mathrm{Cd}, \mathrm{Ni}, \mathrm{Pb}$ & $<0.01$ & $\sim 0.01$ & Primary copper sulfide & 0.008 & 0.221 \\
\hline
\end{tabular}

(Zambia) with those isolated from the Dexing copper mine (China). The strains we isolated belong to three major species commonly encountered in copper heap leaching operations: Acidithiobacillus ferrooxidans (an iron- and sulfur-oxidizing bacterium), Leptospirillum ferriphilum (a bacterium that only oxidizes iron), and Acidithiobacillus thiooxidans (a bacterium that only oxidizes reduced forms of sulfur). These three leaching bacteria have been reported to carry on various interactions (competition, synergism, and mutualism) in bioleaching systems and environment, and the strength of these interactions strongly impacts the global leaching efficiency [12].

This paper extends the study on microbial strains coming from different regions, to compare their physiological characteristics and their leaching efficiencies in their native and foreign ores. It also discusses whether the use of native microbial community is an alternative to overcome the ineffectiveness of available commercial reference strains in the bioleaching of new ores.

\section{Materials and Methods}

2.1. Bacterial Strains and Culture Conditions. Three strains including Acidithiobacillus ferrooxidans FOX1 (Af FOX1 accession number JF934687), Leptospirillum ferriphilum $\mathrm{BN}$ (Lf BN accession number JQ820324), and Acidithiobacillus thiooxidans ZMB (At ZMB accession number JQ820325) were isolated from Chambishi copper mine, Zambia. Acidithiobacillus ferrooxidans YTW (Af YTW accession number DQ062116), Leptospirillum ferriphilum YTW315 (Lf YTW315 accession number EU733647), and Acidithiobacillus thiooxidans (At A02 accession number FJ154540) were isolated from Dexing copper mine, China. Strains were isolated and/or purified by overlay plate (FeSo medium) [13]. The bacteria were cultured in $9 \mathrm{~K}$ medium containing $\left(\mathrm{NH}_{4}\right)_{2} \mathrm{SO}_{4} 3.0 \mathrm{~g}, \mathrm{KCl} 0.1 \mathrm{~g}, \mathrm{~K}_{2} \mathrm{HPO}_{4} 0.5 \mathrm{~g}, \mathrm{MgSO}_{4} \cdot 7 \mathrm{H}_{2} \mathrm{O}$ $0.5 \mathrm{~g}$, and $\mathrm{Ca}\left(\mathrm{NO}_{3}\right)_{2} 0.01 \mathrm{~g}$ in 1 liter of water for 5 days. For At. ferrooxidans and $L$. ferriphilum strains, $9 \mathrm{~K}$ was supplemented with $4.5 \%$ (wt/v) ferrous iron, while for At. thiooxidans $1 \%$ $(w t / v)$ of sulfur was added. Growth and activity of the isolates under normal or various stress conditions, which include $\mathrm{pH}(1.2-3.0)$, temperature $\left(25-45^{\circ} \mathrm{C}\right)$, heavy metals $\left(\mathrm{CuSO}_{4}\right.$ $\left(15-75 \mathrm{mmol} \mathrm{L}^{-1}\right)$ and $\left.\mathrm{Fe}_{2}\left(\mathrm{SO}_{4}\right)_{3} \quad\left(100-600 \mathrm{mmol} \mathrm{L}^{-1}\right)\right)$, and organic compounds such as glucose, sucrose, yeast extract, peptone, and tryptone soya broth $\left(0.1-1 \mathrm{~g} \mathrm{~L}^{-1}\right)$, were examined in $9 \mathrm{~K}$ medium supplemented with ferrous iron and sulfur.
2.2. Bioleaching Experiments. Low grade copper mineral samples were taken from Chambishi copper mine in Zambia $(0.221 \% \mathrm{Cu})$ and Dexing copper mine in China $(0.591 \% \mathrm{Cu})$. The copper moiety of Chambishi mineral sample was mostly composed of free copper oxide (72\%), combined copper oxide (15\%), and secondary copper sulfide (9.5\%) while that of Dexing copper mine was mainly composed of primary copper sulfide (79\%) (Table 1). For both mineral samples, the primary and copper sulfides were mainly composed of chalcopyrite and pyrite, respectively.

Bioleaching tests were carried out in $250 \mathrm{~mL}$ flasks containing $100 \mathrm{~mL} 9 \mathrm{~K}$ medium without ferrous sulfate, under the following conditions: $30^{\circ} \mathrm{C}$, initial $\mathrm{pH} 2.0$, and $170 \times \mathrm{g}$. $9 \mathrm{~K}$ basal salts medium supplemented with $3.0 \%(\mathrm{wt} / \mathrm{v})$ pulp density was used. The inoculums were prepared by growing the microorganisms for 5 days in $500 \mathrm{~mL}$ conical flasks containing $200 \mathrm{~mL}$ of $9 \mathrm{~K}$ medium. For bioleaching with mixed cultures, strains from Chambishi and those from Dexing were equally mixed (same number of cells) to form the Chambishi consortium (ZC) and the Dexing consortium (DC), respectively. In bioleaching, using Dexing ore sample, Dexing strains and Chambishi strains were considered as native and foreign bacteria, respectively, and vice versa for the Chambishi ore. Pure or mixed cultures were inoculated for a final cell density of approximately $10^{6}$ cells $\mathrm{mL}^{-1}$. Abiotic controls were also designed by replacing the bacterial inoculums by an equal volume of related medium. Aliquots of leachate were regularly taken, and redox potential, $\mathrm{pH}$ value, and iron and copper concentrations were analyzed. For the mixed cultures, bacterial compositions were analyzed based on quantitative PCR methods at the middle and the end of the experiment [14]. At the end of the bioleaching experiment, the leaching residues were washed, dried, and subjected to mineral analysis.

2.3. Analytical Methods. Chemical and mineral compositions of the mineral samples and leaching residues were analyzed by ICP-AES (IRIS Advantage 1000) and X-ray diffraction (XRD, D/MAX 2550 VB/PC, Rigaku, Japan), respectively. Ferrous and total iron concentrations in solution were determined by method of dichromate potassium [15] and UV-Vis molecular absorption spectrometry [16], while that of copper was determined by atomic absorption spectrophotometer (AAS). Iron and copper extraction rates were calculated as the ratio of total iron and total copper in leaching liquor to total iron and total copper initially present in the $3 \mathrm{~g}$ of mineral sample, respectively. The $\mathrm{pH}$ value was measured with $\mathrm{pH}$ S-3C acid meter, and the redox potential (or Eh) 
was determined with a platinum electrode with an $\mathrm{Ag} / \mathrm{AgCl}$ reference electrode. Free cells in solution were observed and counted under an optical microscope. All the treatments were done in triplicate unless otherwise mentioned specifically, and the mean and standard deviation of the data from the three independent samples are presented.

\section{Results and Discussion}

3.1. Physiological Properties. Microorganisms used in bioleaching, like any other processes involving living beings, are persistently influenced by environmental, biological, and physicochemical factors, which affect bacterial activities and consequently the yield of metal extraction [17]. So in such work, it is of great importance to study the growth and activity of the isolates under normal or various stress conditions, including $\mathrm{pH}$, temperature, and inhibitory substances such as low molecular weight organic matter and heavy metals.

In terms of energy source, the results revealed that $L$. ferriphilum strains were only iron-oxidizers and At. thiooxidans strains were only sulfur-oxidizers, while At. ferrooxidans could use both ferrous iron and sulfur. None of them could use organic substrates, but they were differently affected by the presence of carbohydrates, such as glucose, sucrose, yeast extract, peptone, and tryptone soya broth (see Table S1 in Supplementary Material available online at http://dx.doi.org/10.1155/2014/787034). For instance, strains of At. ferrooxidans were inhibited by glucose and sucrose but slightly stimulated by peptone and tryptone soya broth at concentration lower than $0.5 \mathrm{~g} \mathrm{~L}^{-1}$, while those of $L$. ferriphilum were inhibited by all these carbon substances. Similar results were reported by Patel et al. [18] who reported that At. ferrooxidans SRDSM2 responded to the addition of $0.5 \mathrm{~g} \mathrm{~L}^{-1}$ peptone and $1.0 \mathrm{~g} \mathrm{~L}^{-1}$ tryptone soya broth (TSB) in the ferrous sulfate tryptone soya broth (ITSB) medium with $35.3 \%$ and $29.6 \%$ increase in iron oxidation rate (IOR) but decrease in the IOR at higher peptone or tryptone soya broth levels [18]. This was more obvious with strain FOX1 (isolated from Chambishi) which scored an increase of IOR of $8.6 \%$ against $2.1 \%$ for strain YTW (isolated from Dexing) when $0.5 \mathrm{~g} \mathrm{~L}^{-1} \mathrm{TSB}$ was added (see Figure S1 in Supplementary Material). From the obtained results, it is hard to speculate the mechanisms involved in this particular response of At. ferrooxidans strains on peptone and tryptone; however, it might be an interesting future research focus. Nevertheless this result confirms the higher tolerance of At. ferrooxidans species to organic matter and may explain the reason why members of At. ferrooxidans are much easier to grow on agar plate than L. ferriphilum strains $[13,19]$. Again, for a given species, strains used the same energy source and responded similarly to the different organic compound; however, there was a slight difference in terms of metabolic activity. Strains isolated from Chambishi were found to have higher growth and iron oxidation rate. For instance, At. ferrooxidans FOX1 (isolated from Chambishi) and At. ferrooxidans YTW (isolated from China) showed an increase in cell density from $\sim 10^{6}$ to $7.14 \times 10^{7}$ and 5.23 $\times 10^{7}$ cells $\mathrm{mL}^{-1}$ (Figures $1(\mathrm{a})$ and $1(\mathrm{c})$ ) with an iron oxidation rate of 72.6 and $67.1 \mathrm{mg} \mathrm{L}^{-1} \mathrm{~h}^{-1}$ (Figures $1(\mathrm{~b})$ and $1(\mathrm{~d})$ ) within 5 days in $9 \mathrm{~K}$ medium containing $4.5 \%(\mathrm{w} / \mathrm{v})$ of ferrous sulfate, respectively.

The influence of initial $\mathrm{pH}$ and temperature on the isolates' growth and metabolic activity was also determined. As can be seen from Figure 1, L. ferriphilum strains presented more interesting characteristics for their use in bioleaching, as they showed higher growth and iron oxidation rate at low $\mathrm{pH}$ and high temperature. At $\mathrm{pH}>1.6$, At. ferrooxidans scored a higher iron oxidation rate, but at $\mathrm{pH}<1.6 \mathrm{~L}$. ferriphilum strains were found more efficient (Figure 1(b)). At temperature ranging between 30 and $35^{\circ} \mathrm{C}$, At. ferrooxidans and At. thiooxidans presented higher cell density with higher activity, but around $40^{\circ} \mathrm{C}$ only growth of L. ferriphilum occurred (Figures 1(c) and 1(d)). This is important to be pointed out because these parameters impact not only the growth and activity of leaching bacteria but also the leaching kinetics of sulfide minerals [17]. By hindering ferric ion precipitation within the heap bed, low $\mathrm{pH}$ promotes heap permeability and the availability of the ferric ion reagent for the leaching of most sulfide minerals, whereas high temperature increases kinetics of chemical reaction involved in such mineral dissolution [20]. Again, under the same stress of $\mathrm{pH}$ and temperature, strains isolated from Chambishi showed higher activity, as noticed in normal condition (Figure 1).

Tolerance to metal ions (specifically ferric and copper ions) is an important factor for a leaching strain to be used in metal extraction and bioextraction of metals from copper mineral sulfide ores, as it results in dissolution of copper and iron as major soluble metals in the leachate; therefore, it was of interest to determine the influence of copper and ferric iron on the growth and activity of the strains. As can be seen from the results shown in Figure 2, Leptospirillum ferriphilum strains, whether they are from Chambishi or Dexing, both showed the highest tolerance to ferric ion. This result is consistent with many reports assuming that members of Leptospirillum ferriphilum species are less sensitive to ferric iron than those of Acidithiobacillus ferrooxidans and Acidithiobacillus thiooxidans, and at high redox potential (due to high ferric/ferrous iron ratio) they outcompete Acidithiobacillus genus [21, 22]. This property allows Leptospirillum sp. to play a pivotal role in mineral sulfide dissolution and specially during the late stage of metal sulfide leaching in which the high concentration of metal ions and Eh hinder the activity of leaching bacteria such as At. ferrooxidans species. In fact, at low temperature (30 to $40^{\circ} \mathrm{C}$ ), Acidithiobacillus ferrooxidans and Leptospirillum ferriphilum are the main producers of ferric ions (1), which assures the chemical dissolution of metal sulfides (2), where Me represents metal ions:

$$
\begin{gathered}
4 \mathrm{Fe}^{2+}+\mathrm{O}_{2}+4 \mathrm{H}^{+} \stackrel{\text { At. ferrooxidans }}{\longrightarrow} 4 \mathrm{Fe}^{3+}+2 \mathrm{H}_{2} \mathrm{O} \\
\mathrm{MeS}+\mathrm{Fe}_{2}\left(\mathrm{SO}_{4}\right)_{3} \longrightarrow \mathrm{MeSO}_{4}+2 \mathrm{FeSO}_{4}+\mathrm{S}^{\mathrm{o}}
\end{gathered}
$$

So, not only do they have to perform a high iron oxidation rate, but they also have to be tolerant to ferric iron. In terms of comparison at origin level, there was not a big difference. 


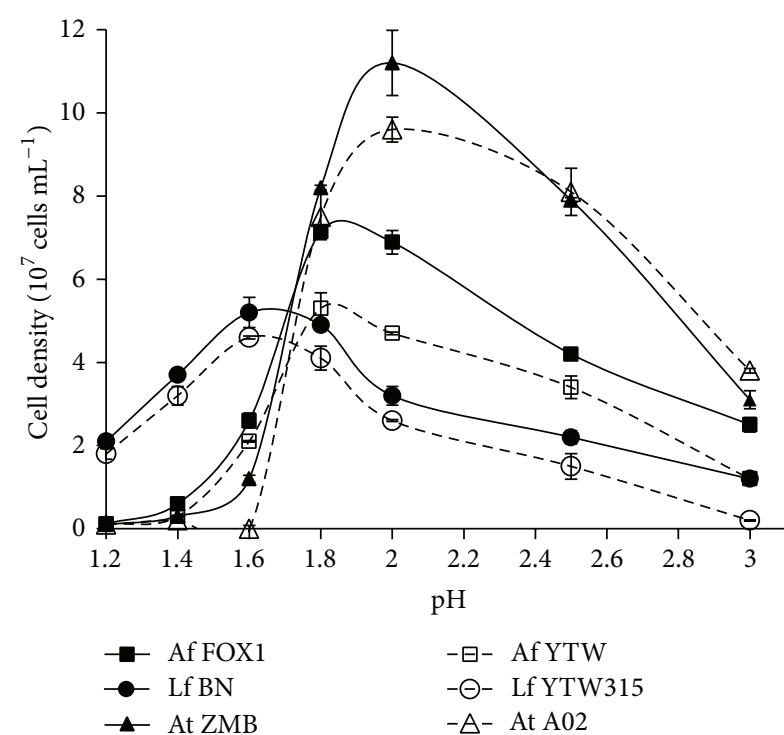

(a)

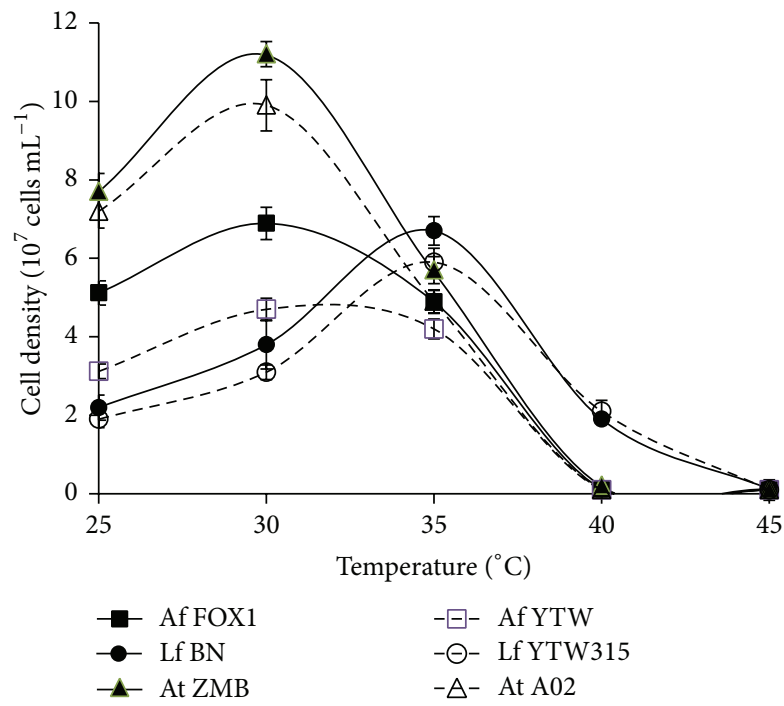

(c)

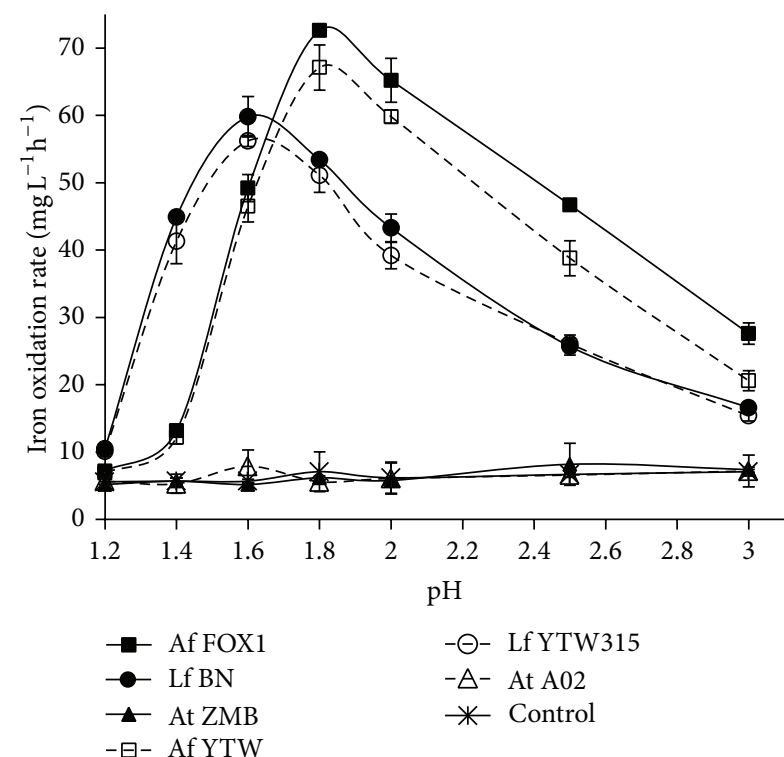

(b)

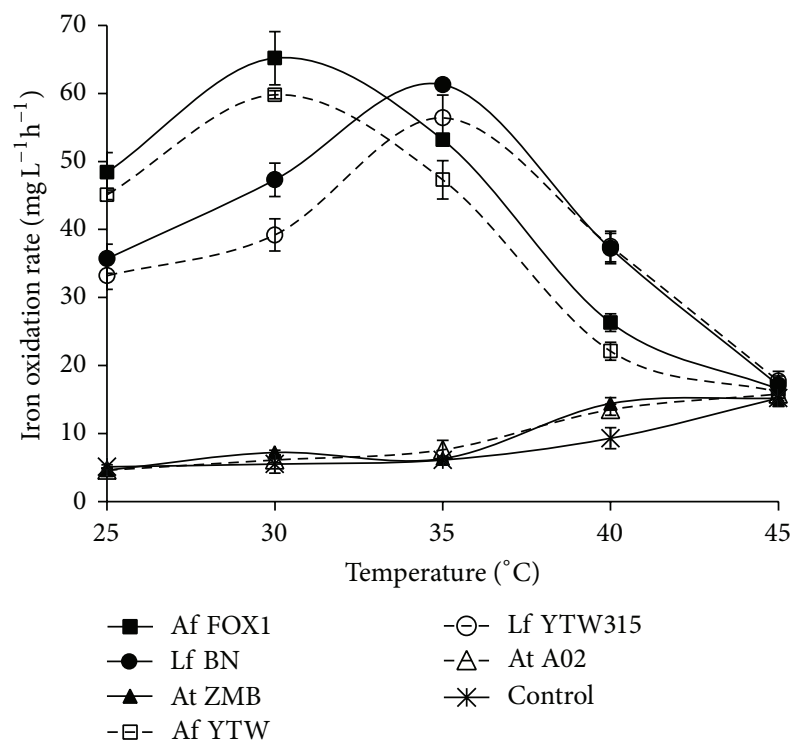

(d)

FIGURE 1: Influence of initial $\mathrm{pH}$ and temperature on cell growth and iron oxidation rates of the Chambishi strains (solid lines) and Dexing strains (long dash lines). Effect of $\mathrm{pH}$ on (a) cell growth and (b) iron oxidation rates of the isolates; effect of temperature on (c) cell growth and (d) iron oxidation rates of the different leaching strains.

For a given species, the strains presented almost the same tolerance to ferric iron, whether they are from Chambishi or Dexing.

Tolerance to copper is an important factor for the use of a strain in copper extraction from copper-bearing minerals, since the copper concentration of the pregnant solution can reach up to $100 \mathrm{mM}$ [23]. Unlike ferric iron, tolerances to copper were slightly different among strains (Figure 2). For At. ferrooxidans strains, YTW (isolated from Dexing) presented a higher copper tolerance than FOX1 (isolated from
Chambishi). In contrast, for L. ferriphilum isolates, that of Chambishi (strain BN) showed a higher copper tolerance than that of Dexing (YTW315). For At. thiooxidans strains, difference was not observed in terms of copper tolerance. Furthermore, unlike ferric ions, the copper resistance was not species-specific.

Basically, all the strains presented interesting properties that can be exploited in bioleaching of mineral sulfides; however, the conditions under which the physiological characterization was carried out were relatively simple and different 


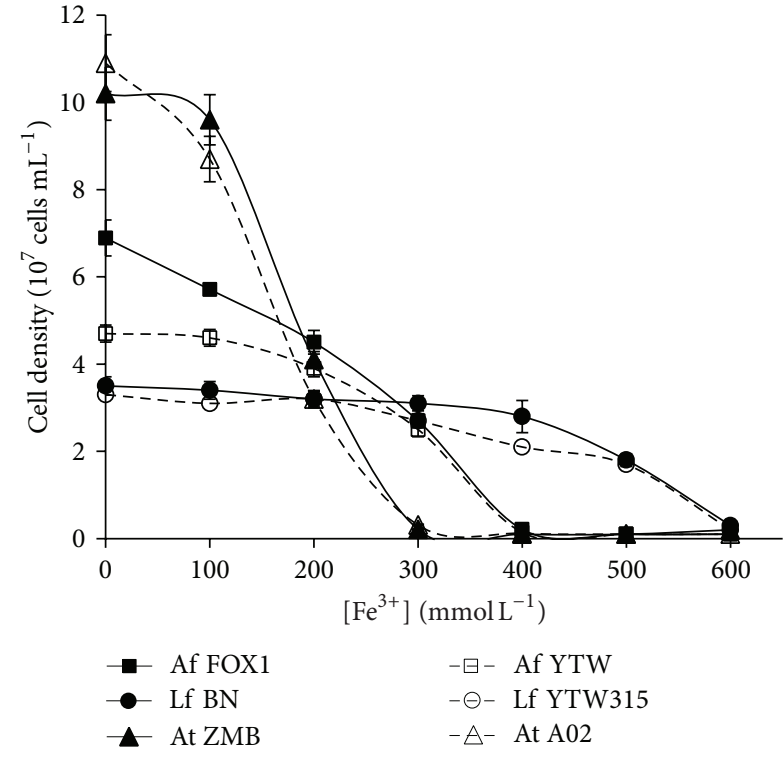

(a)

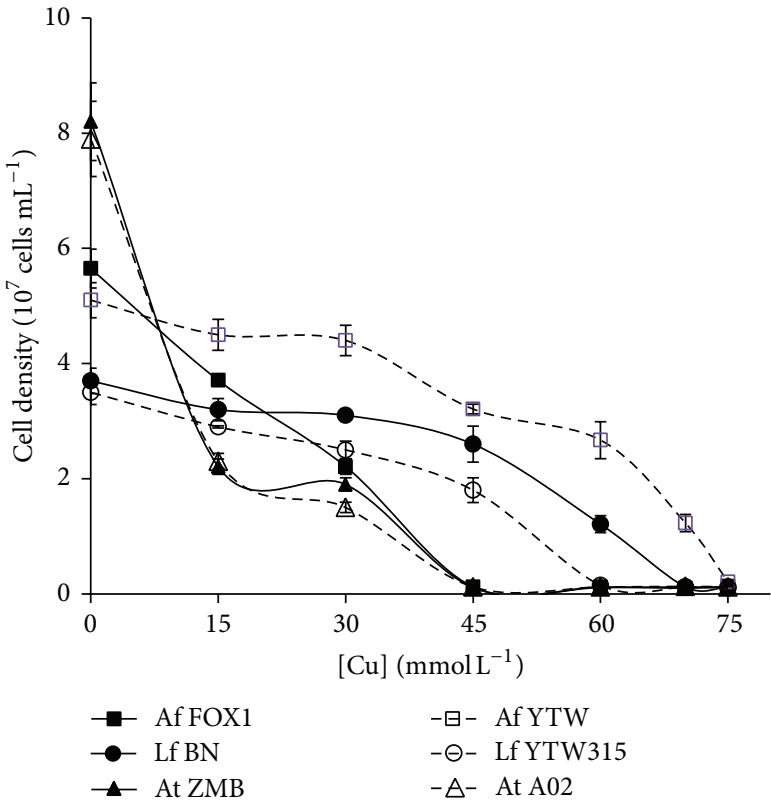

(c)

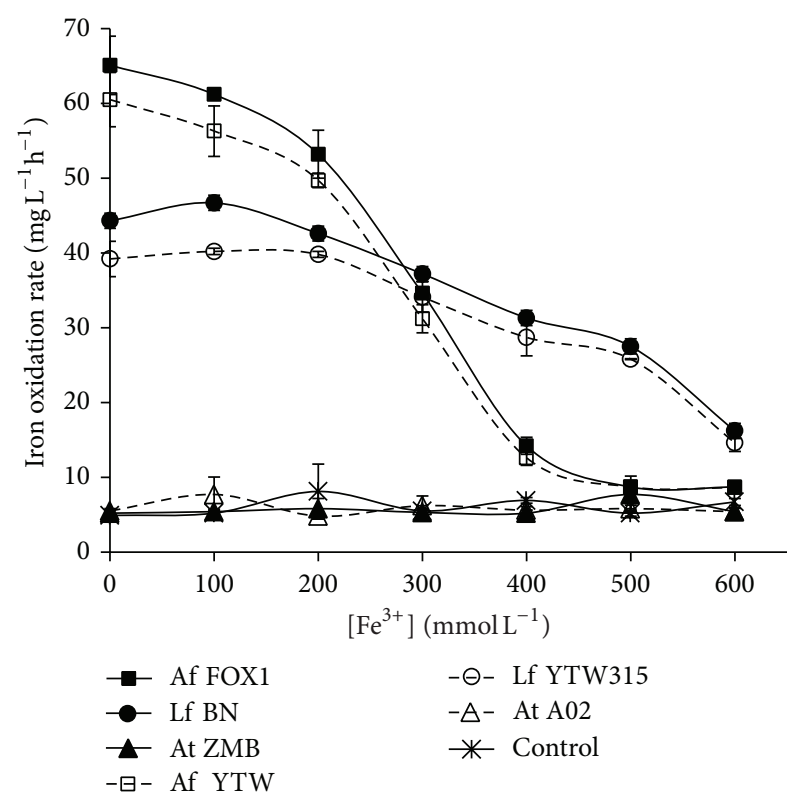

(b)

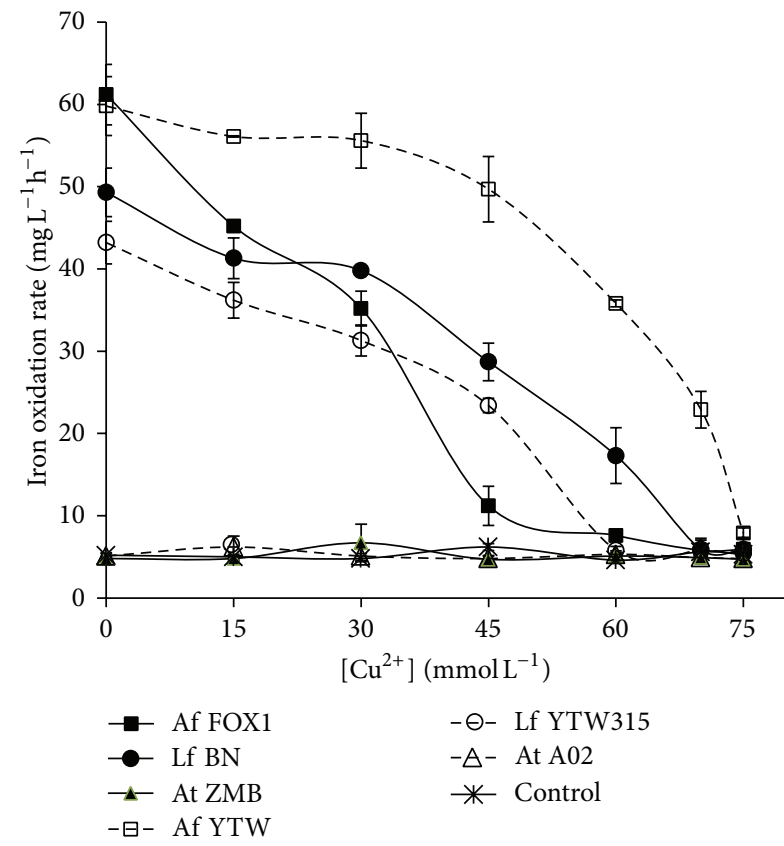

(d)

FIGURE 2: Influence of ferric iron and copper concentration on the growth and activity of the Chambishi strains (solid lines) and Dexing strains (long dash lines). Effect of ferric iron on (a) the growth and (b) the iron oxidation rates of the different strains; effect of copper on (c) the growth and $(\mathrm{d})$ the iron oxidation rates of the strains.

from the complex conditions of leaching environment. So, a study of the strains in leaching environment would give a better insight into their leaching abilities.

3.2. Bioleaching Efficiency. The changes in $\mathrm{pH}$ and cell densities over time are shown in Figure 3. During the first 5 days, an increase in $\mathrm{pH}$ was observed in leaching liquor of both
Dexing and Chambishi mineral samples; and sulfuric acid was added to maintain the $\mathrm{pH}$ at 2.0. This increase in $\mathrm{pH}$ is mainly due to the acid consumption by gangue minerals and the biological oxidation of $\mathrm{Fe}^{2+}$ (1) [24]. After this period, a decrease in $\mathrm{pH}$ was observed, indicating the production of acids through the biological oxidation of elemental sulfur (3) or the precipitation of ferric ions ((4) and (5)). 
TABLE 2: Copper mineral compositions (\% wt/wt) of leaching residues of the Chambishi mineral sample after 30 days of bioleaching using $\mathrm{X}$-ray diffraction (XRD).

\begin{tabular}{lccccccccc}
\hline Copper compounds & & \multicolumn{5}{c}{ Systems } \\
& Af FOX1 & Lf BN & At ZMB & ZC & Af YTW & Lf YTW315 & At A02 & DC & Control \\
\hline Free copper oxide & 0.01 & 0.014 & 0.034 & 0.003 & 0.012 & 0.016 & 0.035 & 0.007 & 0.035 \\
Combined copper oxide & 0.012 & 0.013 & 0.013 & 0.009 & 0.012 & 0.013 & 0.014 & 0.012 & 0.013 \\
Secondary copper sulfide & 0.011 & 0.012 & 0.018 & 0.006 & 0.013 & 0.015 & 0.017 & 0.011 & 0.022 \\
Primary copper sulfide & 0.007 & 0.007 & 0.008 & 0.006 & 0.007 & 0.007 & 0.009 & 0.005 & 0.009 \\
\hline Total copper & 0.04 & 0.046 & 0.073 & 0.024 & 0.044 & 0.051 & 0.075 & 0.035 & 0.079 \\
\hline
\end{tabular}

TABLE 3: Copper mineral compositions (\% wt/wt) of leaching residues of the Dexing mineral sample after 30 days of bioleaching using X-ray diffraction (XRD).

\begin{tabular}{|c|c|c|c|c|c|c|c|c|c|}
\hline \multirow{2}{*}{ Copper compounds } & \multicolumn{9}{|c|}{ Systems } \\
\hline & Af FOX1 & Lf $\mathrm{BN}$ & At $\mathrm{ZMB}$ & $\mathrm{ZC}$ & Af YTW & Lf YTW315 & At $\mathrm{A} 02$ & DC & Control \\
\hline Free copper oxide & - & - & - & - & - & - & - & - & - \\
\hline Combined copper oxide & - & - & - & - & - & - & - & - & - \\
\hline Secondary copper sulfide & 0.041 & 0.037 & 0.047 & 0.023 & 0.035 & 0.038 & 0.041 & 0.018 & 0.057 \\
\hline Primary copper sulfide & 0.416 & 0.436 & 0.453 & 0.367 & 0.413 & 0.427 & 0.449 & 0.354 & 0.463 \\
\hline Total copper & 0.457 & 0.473 & 0.496 & 0.389 & 0.448 & 0.465 & 0.490 & 0.372 & 0.523 \\
\hline
\end{tabular}

Consider

$$
\begin{gathered}
2 \mathrm{~S}^{\mathrm{O}}+3 \mathrm{O}_{2}+2 \mathrm{H}_{2} \mathrm{O} \stackrel{\text { At. thiooxidans }}{\longrightarrow} 2 \mathrm{H}_{2} \mathrm{SO}_{4} \\
3 \mathrm{Fe}^{3+}+2 \mathrm{SO}_{4}{ }^{2-}+6 \mathrm{H}_{2} \mathrm{O} \\
\longrightarrow \mathrm{Fe}_{3}\left(\mathrm{SO}_{4}\right)_{2}(\mathrm{OH})_{6}+6 \mathrm{H}^{+} \\
3 \mathrm{Fe}^{3+}+2 \mathrm{HSO}_{4}{ }^{-}+6 \mathrm{H}_{2} \mathrm{O}+\mathrm{M}^{+} \\
\longrightarrow \mathrm{MFe}_{3}\left(\mathrm{SO}_{4}\right)_{2}(\mathrm{OH})_{6}+8 \mathrm{H}^{+}
\end{gathered}
$$

where $\mathrm{M}^{+}=\mathrm{K}^{+}, \mathrm{Na}^{+}$, or $\mathrm{NH}_{4}{ }^{+}$.

The decrease in $\mathrm{pH}$ was noticed in all samples, but it was much more important in systems with mixed culture followed by those with At. ferrooxidans. In fact, At. thiooxidans and, to some extent, At. ferrooxidans are the main producers of acid, through the biooxidation of sulfur (3), in mesophilic condition. So their copresence in mixed culture enhances the production of acid. For the systems with At. thiooxidans, less production of acid can be explained by the absence of sulfur produced through the chemical dissolution of metal sulfides by ferric iron, which cannot be regenerated by At. thiooxidans. In contrast, members of Leptospirillum genus can regenerate ferric iron but cannot oxidize sulfur compound released by mineral sulfide dissolution which explains the slight change in $\mathrm{pH}$ observed in systems inoculated with BN and YTW315. The decrease in $\mathrm{pH}$ in systems inoculated with Leptospirillum is rather a result of the precipitation of ferric iron $((4)$ and (5)) than that of sulfur biooxidation (3). In addition, the decrease in $\mathrm{pH}$ was much more important with native bacteria than foreign microorganisms, indicating higher activities of indigenous than foreign microbes. These results were also consistent with changes in Eh and cell densities. For instance, native microorganisms always achieved higher cell densities than foreign microorganisms (Figure 3). This result demonstrates the ease of native bacteria to adapt to their original ores [11].

The iron and copper extraction rates of Dexing and Chambishi samples bioleaching are depicted in Figure 4. As can be seen, the iron and copper extraction rates followed the same trends, and they were consistent with changes in $\mathrm{pH}$ and cell densities (Figure 3), assuming that there are several interacting parameters in the bacterial leaching of sulfide minerals. Apart from being the relevant agent for metal sulfides dissolution, iron represents also an indicator for leaching efficiency, since it represents itself a product of most of the metal sulfide dissolutions (pyrite, chalcopyrite, and arsenopyrite). So, a high iron extraction rate leads to and indicates a high metal sulfide dissolution rate and consequently a high copper extraction rate. In other words, the iron and copper extraction rates are strongly correlated. Of course, in metal sulfide under the form of $\mathrm{Cu}_{x} \mathrm{Fe}_{y} \mathrm{~S}_{z}$ such as chalcopyrite, this correlation is obvious; but even in metal sulfides in which copper and iron are not combined this correlation stands.

Figure 4 also shows that, for any samples, mixed cultures always performed the highest iron and copper extraction rates. In fact, it is the actions and interactions of different microorganisms with different abilities that provide high leaching efficiency rather than the action of a single microorganism (pure culture) [10]. Each of these three species detains some leaching abilities but not enough to give a high leaching efficiency. These results are in agreement with many reports suggesting that the iron oxidizers (At. ferrooxidans and $L$. ferriphilum) combined with sulfur oxidizers (At. thiooxidans and At. caldus) performed better than pure cultures of any of these three bacterial leaching species $[25,26]$. 


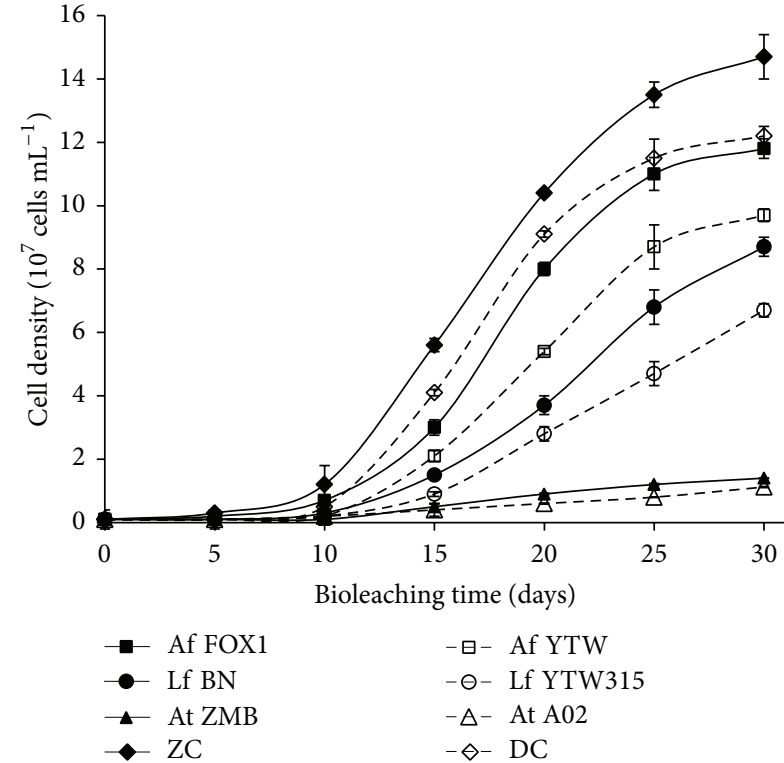

(a)

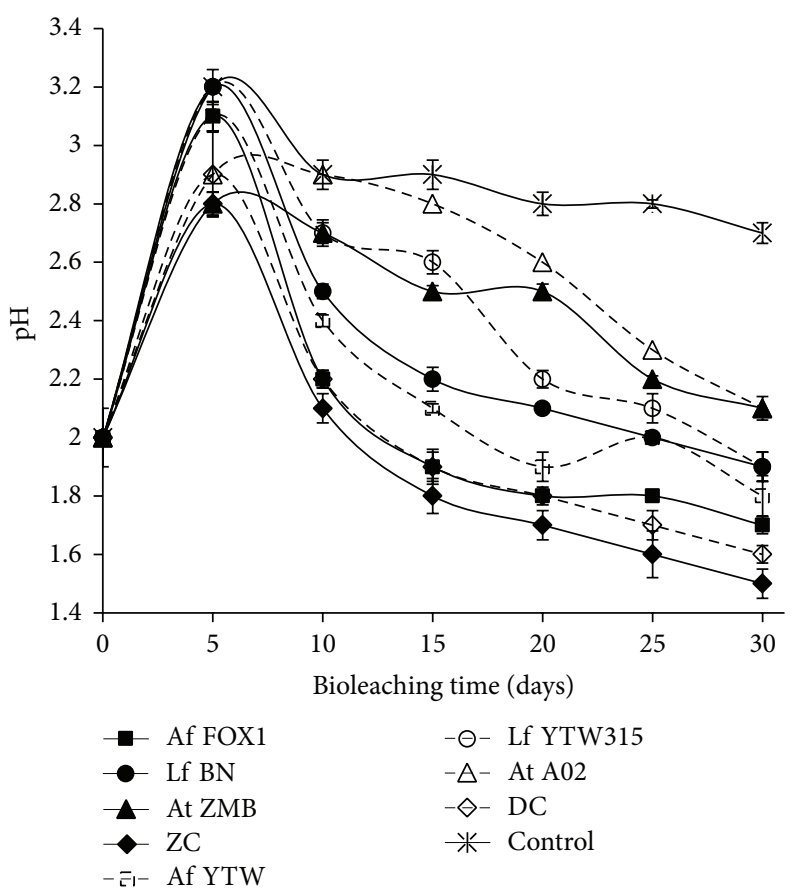

(c)

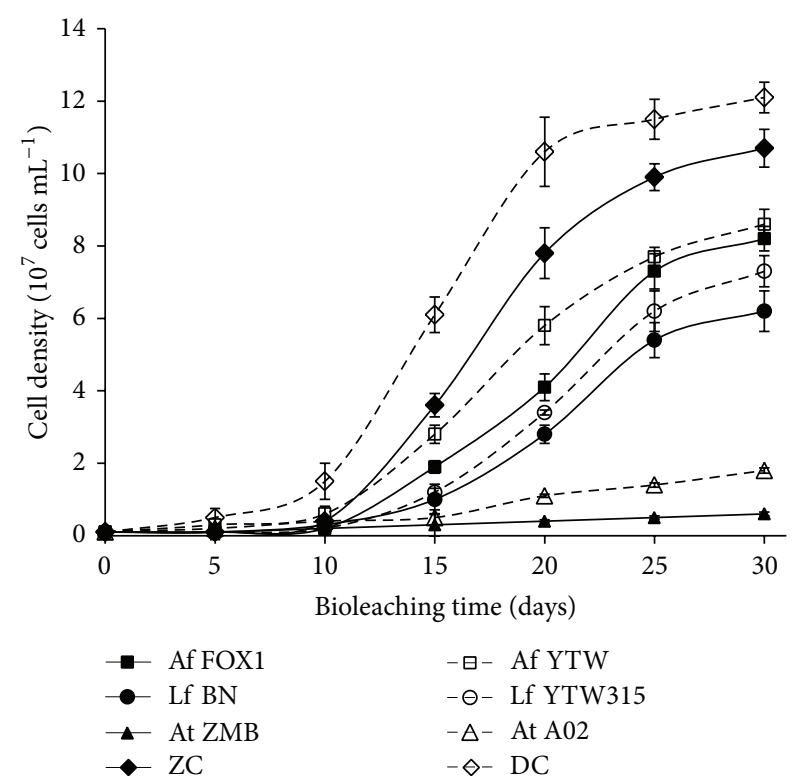

(b)

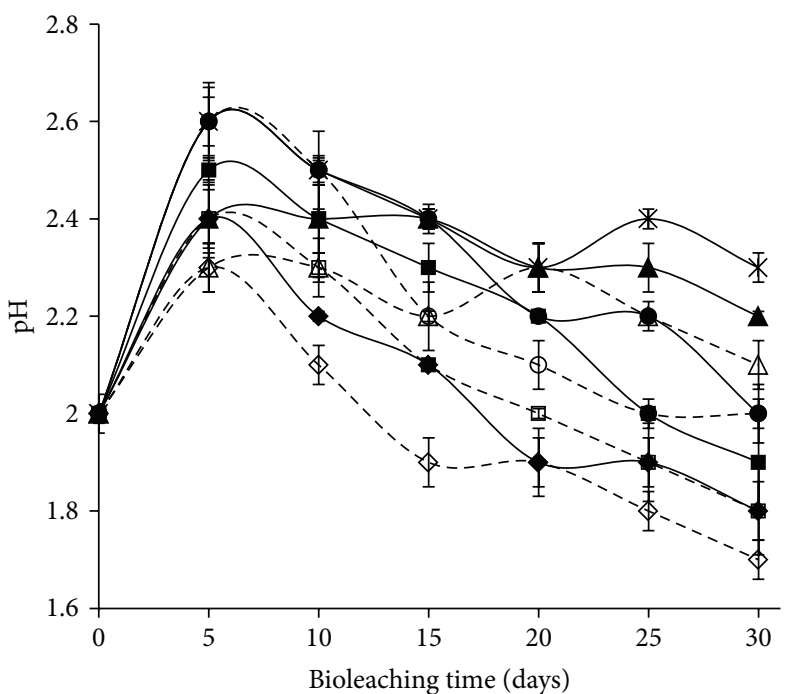

$-\ominus-$ Lf YTW315
$-\triangle-$ At A02
$-\diamond-$ DC
$*$ Control

(d)

FIGURE 3: Changes in cell density and $\mathrm{pH}$ during bioleaching of low grade copper ores from Chambishi and Dexing with Chambishi strains (solid lines) and Dexing strains (long dash lines). Evolution of cell densities in pure and mixed cultures during the bioleaching of (a) Chambishi and (b) Dexing samples; changes in $\mathrm{pH}$ in pure and mixed cultures during the bioleaching of (c) Chambishi and (d) Dexing mineral samples.

Figure 4 reveals also that iron extraction rate was higher with native microorganisms than foreign strains. The same result was also observed in copper extraction rate, indicating that, for a given bacterial species or bacterial population composition, native microorganisms are always more efficient than foreign bacteria. Obviously, the microorganisms involved for setting in proper physicochemical changes like
Eh, $\mathrm{pH}$, temperature, and concentration of metals and metalloids into the system leading to mineral oxidation and dissolution are of particular significance [27]. However, the type of ores and the ease of the microorganism to adapt to it impact a lot the time that the leaching microorganisms take to create adequate mineral dissolution conditions [11, 27]. In the case of this study, foreign microorganisms were found 


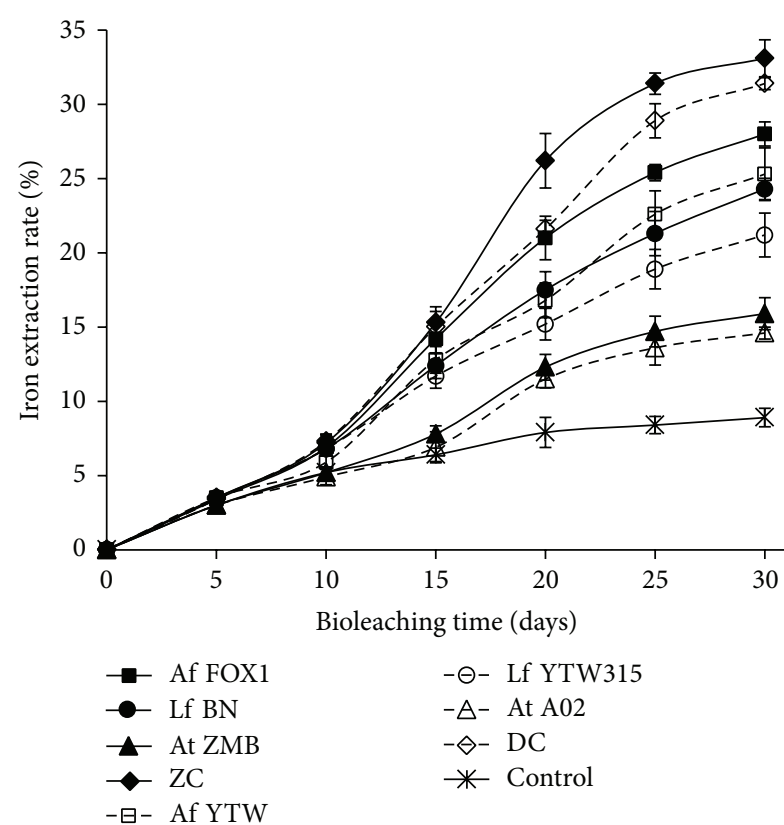

(a)

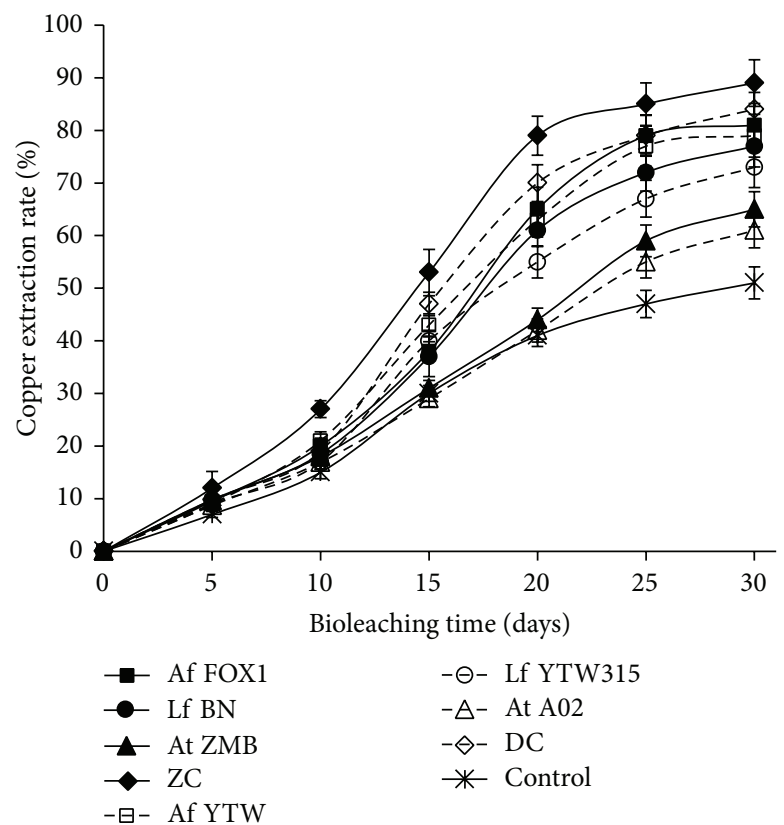

(c)

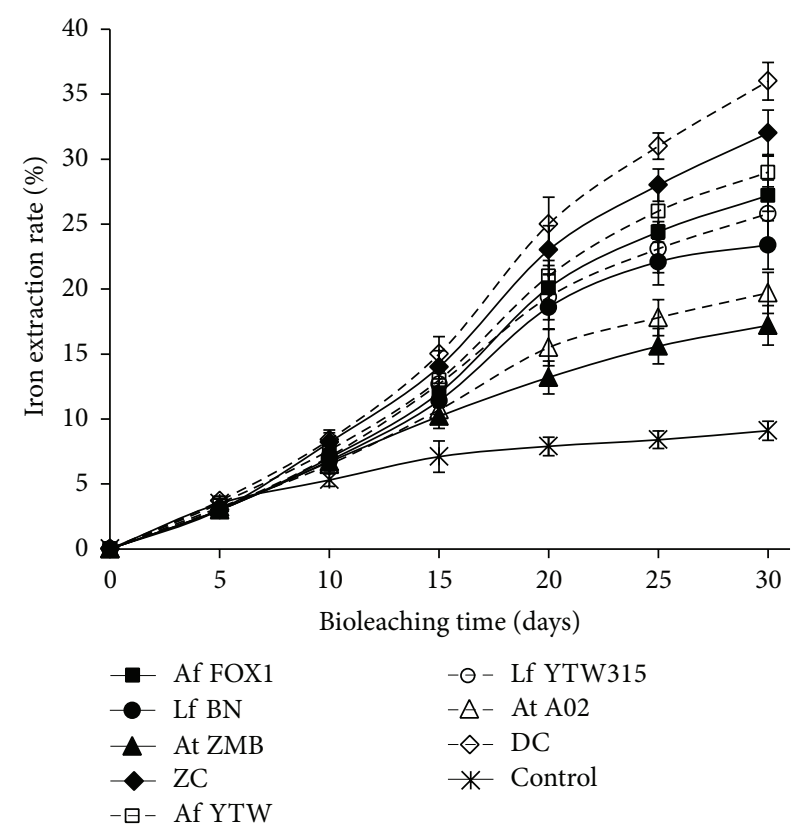

(b)

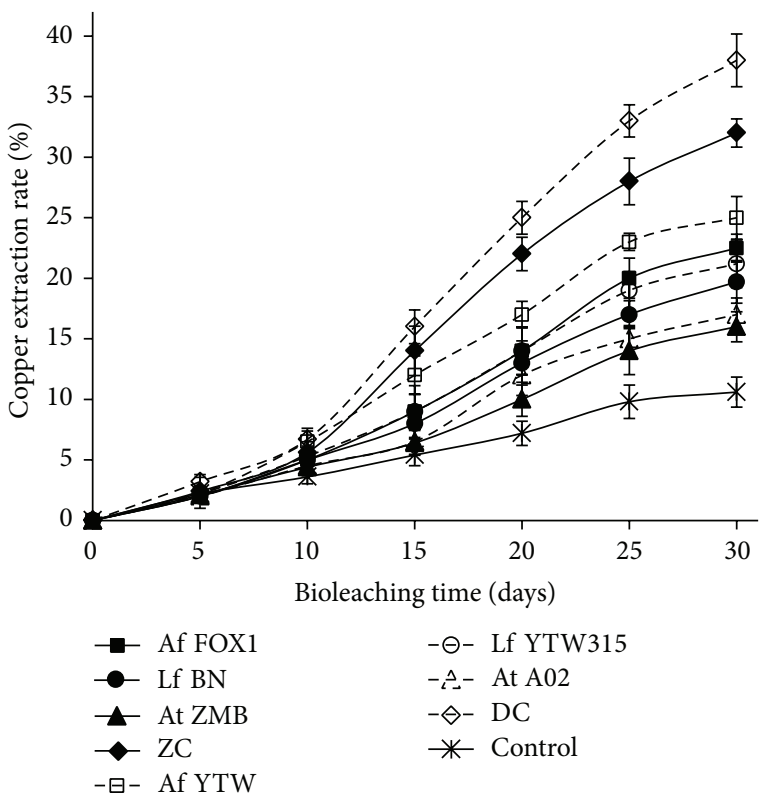

(d)

Figure 4: Iron and copper extraction rates during bioleaching of low grade copper ores from Chambishi and Dexing with Chambishi strains (solid lines) and Dexing strains (long dash lines). Iron extraction rates of (a) Chambishi and (b) Dexing mineral samples; copper extraction rates of (c) Chambishi and (d) Dexing mineral samples.

to observe a longer lag phase than the native strains and consequently a delay in generating suitable conditions (high Eh and ferric iron concentration and low $\mathrm{pH}$ ) for metal sulfide dissolution. These results demonstrate that the use of native microbes, even though the recovery of the suitable one is challenging, constitutes an option for increasing viability and improving metal extraction efficiency.
The composition of the copper moiety in the leaching residues of the Chambishi sample is presented in Table 2, while that of the Dexing mineral sample is shown in Table 3. Great changes have been noticed in the three forms of copper (free copper oxides, combined copper oxides, and secondary copper sulfides); however, the primary copper sulfide ratios in the residues were almost similar to those of the mineral 


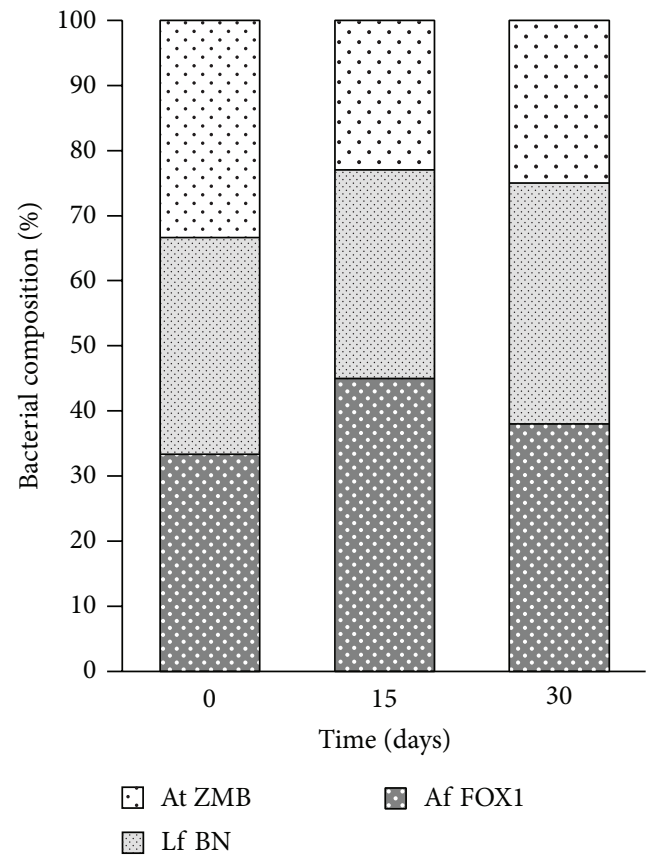

(a)

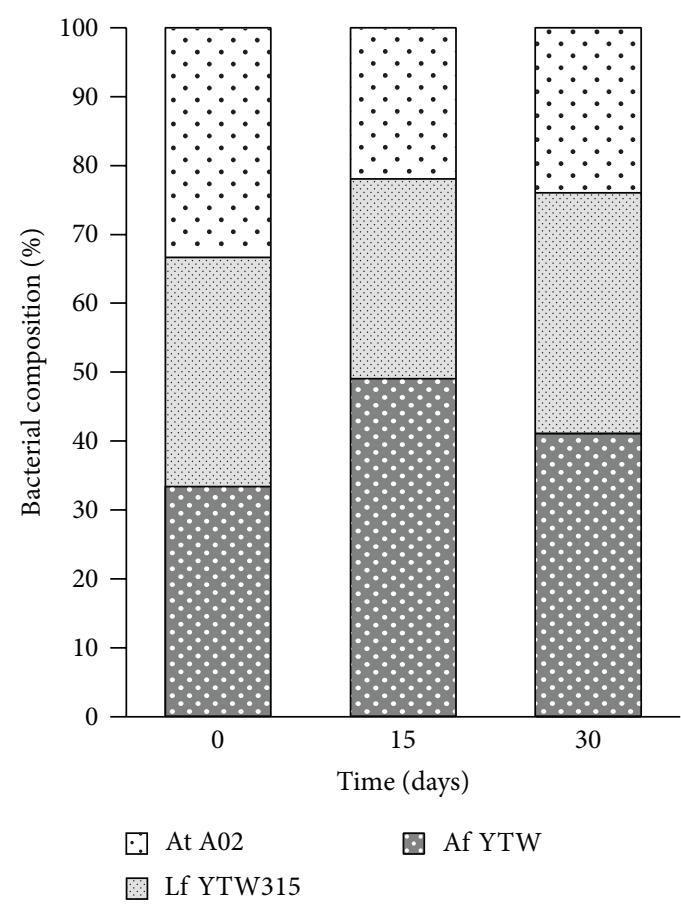

(c)

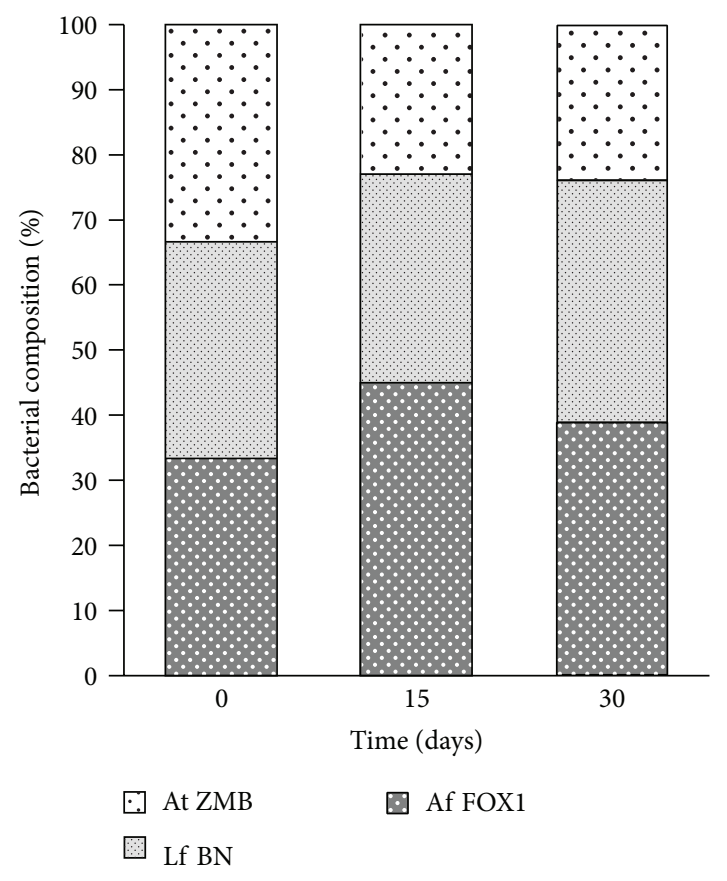

(b)

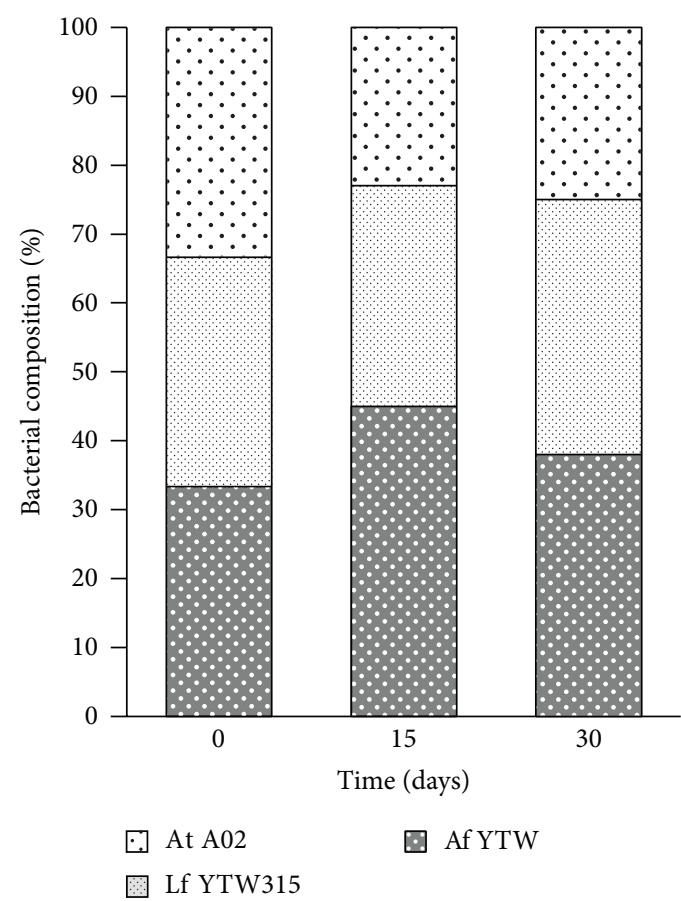

(d)

FIGURE 5: Changes in bacterial composition in mixed cultures systems. Bacterial composition of Chambishi consortium during the bioleaching of (a) Chambishi and (b) Dexing mineral samples; bacterial composition of Dexing consortium during the bioleaching of (c) Chambishi and (d) Dexing mineral samples.

samples (Tables 1, 2, and 3), suggesting that the latter was not effectively leached. It has been reported that, under mesophilic bioleaching conditions, primary copper sulfides, such as chalcopyrite, are often characterized by the slow dissolution kinetics and incomplete dissolution due to their refractory character, which is controversially attributed to the occurrence of a passivation layer on the mineral surface by elemental sulfur, ferric precipitates, or intermediate copper polysulfides [20, 25]. An effective bioleaching of such mineral sulfide requires high temperature [28] and low $\mathrm{pH}$ and 
consequently bacteria that can work under such condition (thermophilic or moderately thermophilic microorganisms). Considering the condition $\left(30^{\circ} \mathrm{C}\right)$ under which the experiment was carried out, these results make sense; they are even in agreement with the copper extraction rate which revealed that the Chambishi ore sample (mostly composed of copper oxides and secondary copper sulfides) was easier to be leached than the Dexing ore sample (mainly composed of primary copper sulfides) (Figure 4).

3.3. Bacterial Population Analysis. Leaching bacteria do not only live in perfect symbiotic association in leaching environment; they may have a competition between them leading to changes in microbial population composition overtime. Changes in microbial population composition and structure are mainly according to the environmental conditions $(\mathrm{pH}$, temperature, Eh, substrates, and inhibitors) which evolve also according to the microbial community activity. In this study, At. ferrooxidans strains (FOX1 and YTW) were found to be the dominant strains followed by L. ferriphilum strains (BN and YTW315) in all mixed cultures systems (Figure 5). For instance, in the bioleaching of the Chambishi sample with Chambishi strains, the percentage of At. ferrooxidans FOX1 increased from $33 \%$ to $47 \%$ during the first 15 days and then decreased to $40 \%$ on the 30 th day. In contrast, that of $L$. ferriphilum BN decreased slightly during the first 15 days and then increased to $\sim 37 \%$ on the 30 th day. At. thiooxidans strains represented the lowest percentage. From 33\%, their ratios decreased to $21 \%$ on the 15 th day and remained almost the same $(23 \%)$ at the end of the experiment. Similar results were also obtained with Dexing strains. These results are consistent with cells density in systems with pure culture, in which those inoculated with At. ferrooxidans strains always showed the highest cell density (Figure 3 ). Indeed, the condition under which the experiment was carried out is more suitable to At. ferrooxidans growth (compared to $L$. ferriphilum). Another reason is the versatility of members of this species in terms of substrate, unlike the two other species; members of At. ferrooxidans can use both ferrous ions and sulfur, and then have less susceptibility to encounter nutrient deficiency. In the last 10 days, L. ferriphilum strains tended to outcompete At. ferrooxidans isolates, and this was more obvious with bioleaching of Dexing mineral sample, in which the percentage of L. ferriphilum became almost equal to that of At. ferrooxidans. For instance, in system of the Dexing sample bioleaching with Dexing strains, the ratio of At. ferrooxidans and L. ferriphilum reached $38 \%$ and $37 \%$, respectively (Figure 5). This phenomenon can be attributed to the increase in ferric iron [21, 22, 29]. Another explanation is the decrease of $\mathrm{pH}$ to which At. ferrooxidans is more sensitive than L. ferriphilum [7].

\section{Conclusions}

Physiological properties and leaching performances of six strains isolated from Chambishi (Chambishi) and Dexing (China) copper mines were characterized. The results revealed that, except for copper tolerance, strains within species presented almost similar physiological traits with slight advantages of Chambishi strains. Despite the slight physiological advantages of the Chambishi strains over the Dexing strains, the latter were more efficient for the bioleaching of the Dexing mineral sample, and vice versa. These results confirmed the fact that physiological characteristics are not cumulative, and a microbial community composed of microorganisms with the most interesting physiological traits would not necessarily provide the best leaching efficiency. This study also revealed that native strains were always more effective than foreign microorganisms for the bioleaching of a given ore, suggesting that the use of native microorganisms would be an interesting alternative to overcome the ineffectiveness of available commercial reference strains for the bioleaching of new mineral sulfide ores.

\section{Conflict of Interests}

The authors declare that there is no conflict of interests regarding the publication of this paper.

\section{Acknowledgments}

This work was supported by the High Tech Research and Development Program (863 Program: 2012AA061502) and the National Key Basic Research Program of China (973 Program no. 2010CB630901).

\section{References}

[1] D. Bevilaqua, H. A. Acciari, A. V. Benedetti, and O. J. Garcia, "Electrochemical techniques used to study bacterialmetal sulfides interactions in acidic environment," in Microbial Processing of Metal Sulfides, E. R. Donati and S. Wolfgang, Eds., pp. 59-76, Springer, Dordrecht, The Netherlands, 2007.

[2] T. Rohwerder and W. Sand, "Mechanisms and biochemical fundamentals of bacterial metal sulfide oxidation," in Microbial Processing of Metal Sulfides, pp. 35-38, Springer, 2007.

[3] A. Schippers and W. Sand, "Bacterial leaching of metal sulfides proceeds by two indirect mechanisms via thiosulfate or via polysulfides and sulfur," Applied and Environmental Microbiology, vol. 65, no. 1, pp. 319-321, 1999.

[4] M. Vera, A. Schippers, and W. Sand, "Progress in bioleaching: fundamentals and mechanisms of bacterial metal sulfide oxidation-part A," Applied Microbiology and Biotechnology, vol. 97, pp. 7529-7541, 2013.

[5] T. Rohwerder, T. Gehrke, K. Kinzler, and W. Sand, "Bioleaching review part A: progress in bioleaching: Fundamentals and mechanisms of bacterial metal sulfide oxidation," Applied Microbiology and Biotechnology, vol. 63, no. 3, pp. 239-248, 2003.

[6] A. Schippers, "Microorganisms involved in bioleaching and nucleic acid-based molecular methods for their identification and quantification," in Microbial Processing of Metal Sulfides, E. R. Donati and W. Sand, Eds., pp. 3-33, Springer, Houten, The Netherlands, 2007.

[7] P. R. Norris, "Acidophile diversity in mineral sulfide oxidation," in Biomining, D. E. Rawlings and D. B. Johnson, Eds., pp. 199216, Springer, Heidelberg, Germany, 2007. 
[8] J. Plumb, R. B. Hawkes, and P. D. Franzmann, "The microbiology of moderately thermophilic and transiently thermophilic ore heaps," in Biomining, D. E. Rawlings and B. Johnson, Eds., pp. 217-235, Springer, Heidelberg, Germany, 2007.

[9] D. E. Rawlings and D. B. Johnson, "The microbiology of biomining: development and optimization of mineral-oxidizing microbial consortia," Microbiology, vol. 153, no. 2, pp. 315-324, 2007.

[10] N. Pradhan, K. C. Nathsarma, K. Srinivasa Rao, L. B. Sukla, and B. K. Mishra, "Heap bioleaching of chalcopyrite: a review," Minerals Engineering, vol. 21, no. 5, pp. 355-365, 2008.

[11] S. M. Mousavi, S. Yaghmaei, M. Vossoughi, A. Jafari, R. Roostaazad, and I. Turunen, "Bacterial leaching of low-grade $\mathrm{ZnS}$ concentrate using indigenous mesophilic and thermophilic strains," Hydrometallurgy, vol. 85, no. 1, pp. 59-65, 2007.

[12] B. Fu, H. Zhou, R. Zhang, and G. Qiu, "Bioleaching of chalcopyrite by pure and mixed cultures of Acidithiobacillus spp. and Leptospirillum ferriphilum," International Biodeterioration and Biodegradation, vol. 62, no. 2, pp. 109-115, 2008.

[13] D. B. Johnson and K. B. Halberg, "Techniques for detecting and identifying acidophilic mineral-oxidizing microorganisms," in Biomining, pp. 237-261, Springer, Berlin, Germany, 2007.

[14] C. Bowei, L. Xingyu, L. Wenyan, and W. Jiankang, "Application of clone library analysis and real-time PCR for comparison of microbial communities in a low-grade copper sulfide ore bioheap leachate," Journal of Industrial Microbiology and Biotechnology, vol. 36, no. 11, pp. 1409-1416, 2009.

[15] A. Vogel, A Textbook of Quantitative Inorganic Analysis, ELBS and Longman, London, UK, 3rd edition, 1962.

[16] S. Dobrinas, A. Soceanu, C. B. Gheorghiu, and M. Tanase, Comparative Methods Applied for the Determination of Total Iron, Ovidius University Press, Constanta, Romania, 2010.

[17] T. V. Ojumu and J. Petersen, "The kinetics of ferrous ion oxidation by Leptospirillum ferriphilum in continuous culture: the effect of pH," Hydrometallurgy, vol. 106, no. 1-2, pp. 5-11, 2011.

[18] M. J. Patel, D. R. Tipre, and S. R. Dave, "Isolation, identification, characterization and polymetallic concentrate leaching studies of tryptic soy- and peptone-resistant thermotolerant Acidithiobacillus ferrooxidans SRDSM2," Bioresource Technology, vol. 102, no. 2, pp. 1602-1607, 2011.

[19] D. B. Johnson and S. McGinness, "A highly efficient and universal solid medium for growing mesophilic and moderately thermophilic, iron-oxidizing, acidophilic bacteria," Journal of Microbiological Methods, vol. 13, no. 2, pp. 113-122, 1991.

[20] H.-B. Zhou, W.-M. Zeng, Z.-F. Yang, Y.-J. Xie, and G.-Z. Qiu, "Bioleaching of chalcopyrite concentrate by a moderately thermophilic culture in a stirred tank reactor," Bioresource Technology, vol. 100, no. 2, pp. 515-520, 2009.

[21] M. Boon, J. Heijnen, and G. Hansford, "The mechanism and kinetics of bioleaching sulphide minerals," Mineral Processing and Extractive Metallurgy Review, vol. 19, pp. 107-115, 1998.

[22] B. C. Patel, D. R. Tipre, and S. R. Dave, "Development of Leptospirillum ferriphilum dominated consortium for ferric iron regeneration and metal bioleaching under extreme stresses," Bioresource Technology, vol. 118, pp. 483-489, 2012.

[23] A. Orell, C. A. Navarro, R. Arancibia, J. C. Mobarec, and C. A. Jerez, "Life in blue: copper resistance mechanisms of bacteria and Archaea used in industrial biomining of minerals," Biotechnology Advances, vol. 28, no. 6, pp. 839-848, 2010.
[24] H. R. Watling, "The bioleaching of sulphide minerals with emphasis on copper sulphides-a review," Hydrometallurgy, vol. 84, no. 1-2, pp. 81-108, 2006.

[25] A. Akcil, H. Ciftci, and H. Deveci, "Role and contribution of pure and mixed cultures of mesophiles in bioleaching of a pyritic chalcopyrite concentrate," Minerals Engineering, vol. 20, no. 3, pp. 310-318, 2007.

[26] L.-X. Xia, J.-S. Liu, L. Xiao et al., "Single and cooperative bioleaching of sphalerite by two kinds of bacteriaAcidithiobacillus ferriooxidans and Acidithiobacillus thiooxidans," Transactions of Nonferrous Metals Society of China, vol. 18, no. 1, pp. 190-195, 2008.

[27] S. E. Keeling, M.-L. Palmer, F. C. Caracatsanis, J. A. Johnson, and H. R. Watling, "Leaching of chalcopyrite and sphalerite using bacteria enriched from a spent chalcocite heap," Minerals Engineering, vol. 18, no. 13-14, pp. 1289-1296, 2005.

[28] E. Gómez, A. Ballester, F. González, and M. L. Blázquez, "Leaching capacity of a new extremely thermophilic microorganism, Sulfolobus rivotincti," Hydrometallurgy, vol. 52, no. 3, pp. 349366, 1999.

[29] B. C. Patel, D. R. Tipre, and S. R. Dave, “Optimization of copper and zinc extractions from polymetallic bulk concentrate and ferric iron bioregeneration under metallic stress," Hydrometallurgy, vol. 117-118, pp. 18-23, 2012. 

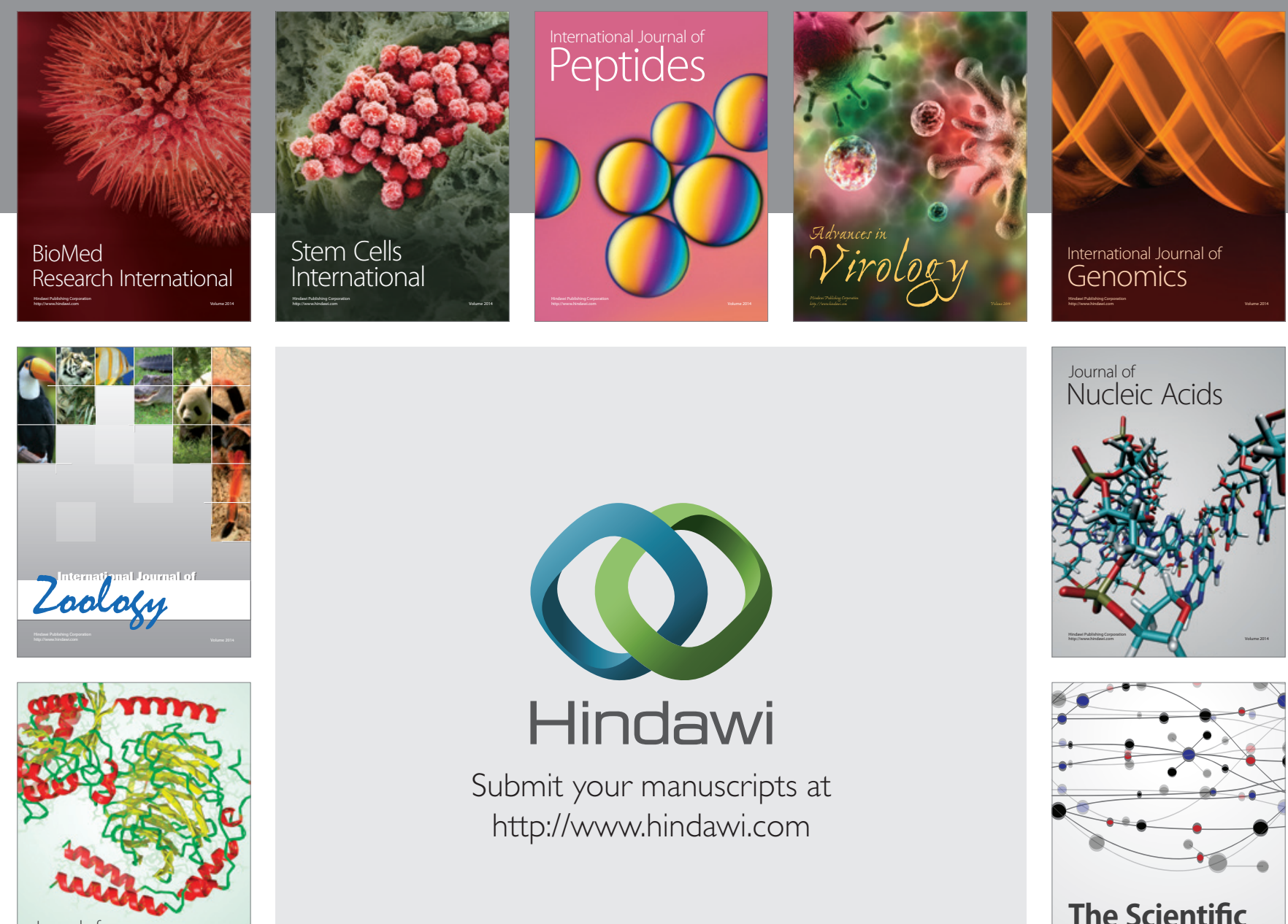

Submit your manuscripts at

http://www.hindawi.com

Journal of
Signal Transduction
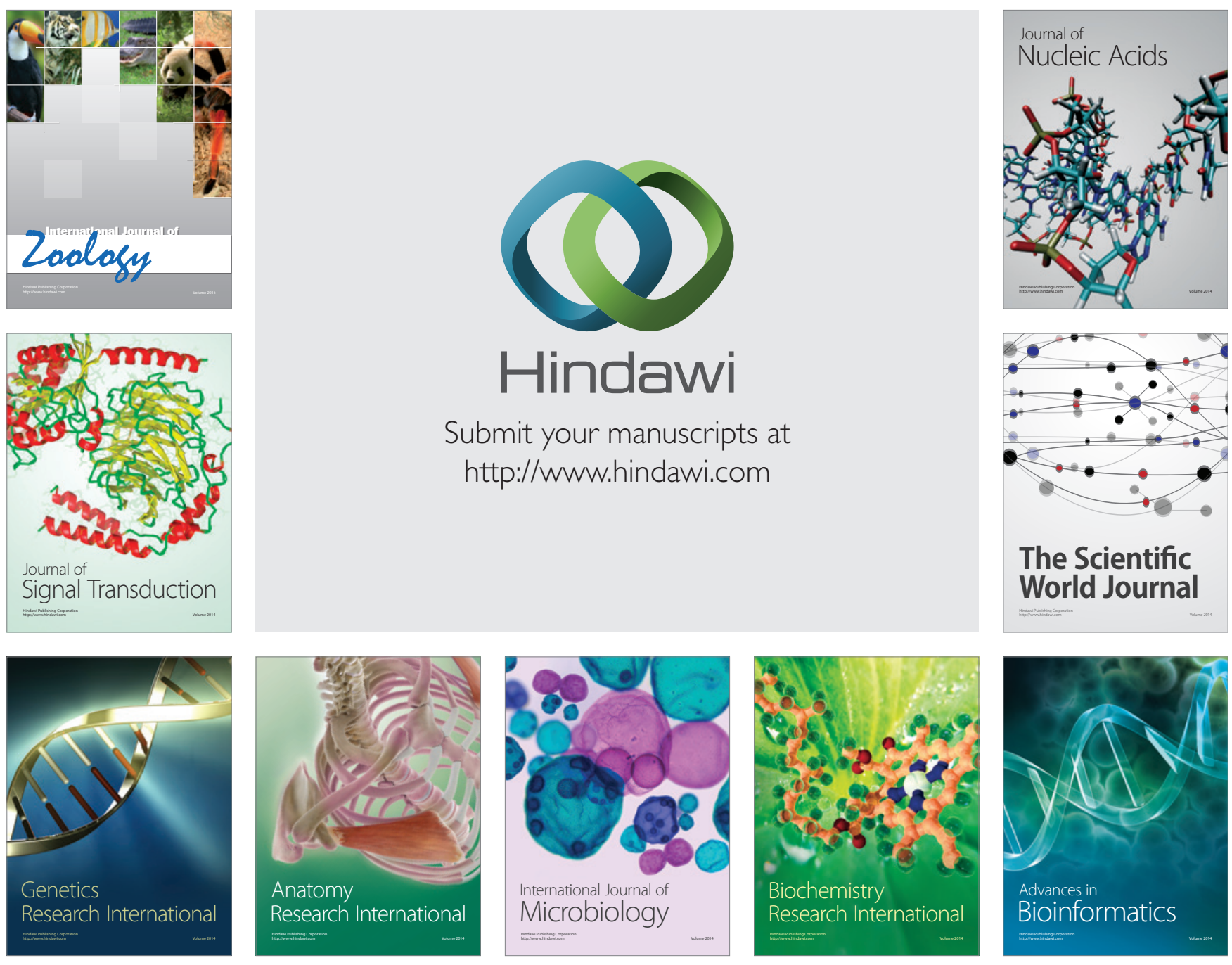

The Scientific World Journal
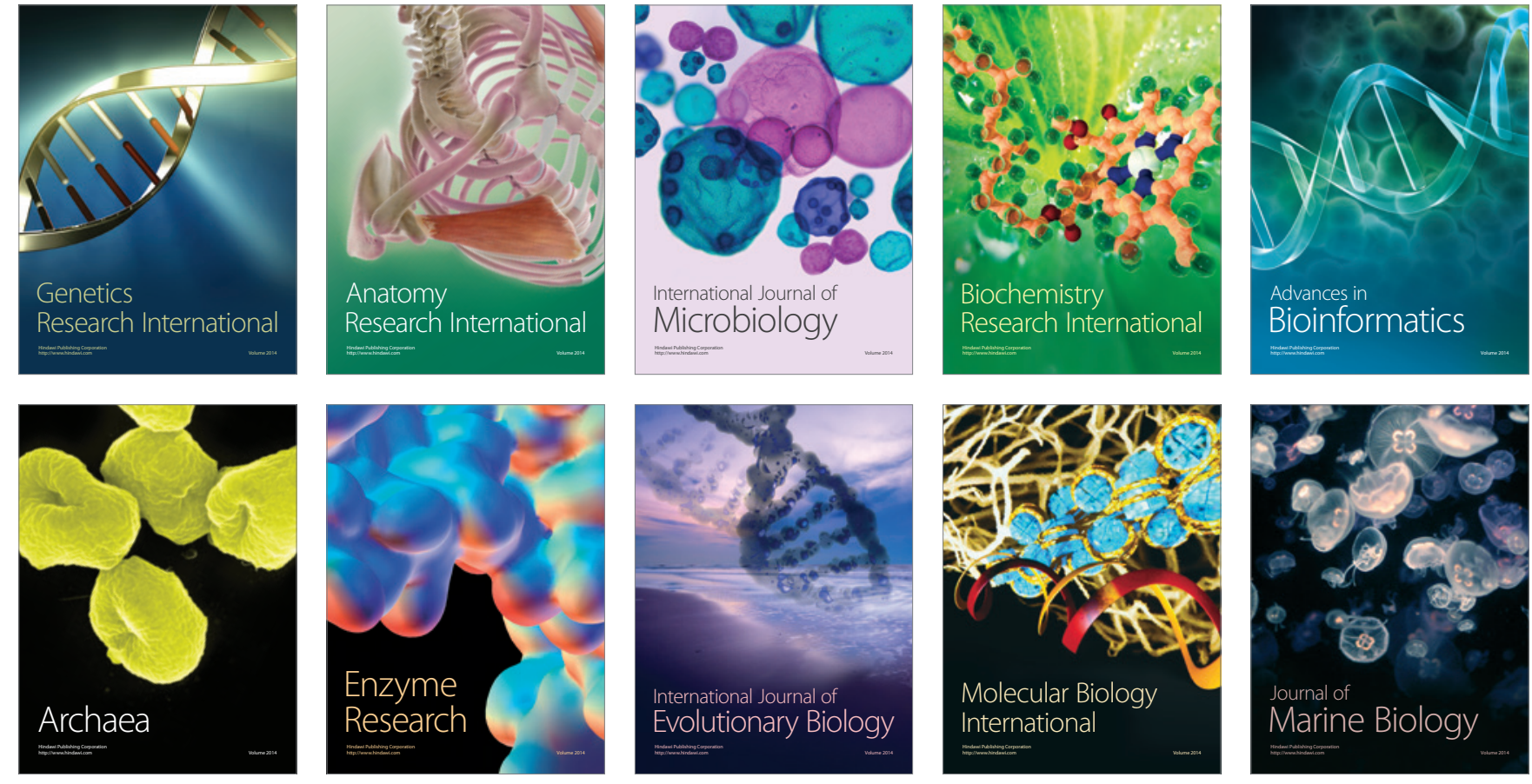